\title{
Hormonal Regulation of Serum Lp (a) Levels \\ Opposite Effects after Estrogen Treatment and Orchidectomy in Males with Prostatic Carcinoma
}

Peter Henriksson, Bo Angelin, and Lars Berglund

Metabolism Unit, Departments of Medicine and Clinical Chemistry, Karolinska Institutet at Huddinge University Hospital, S-141 86 Huddinge, Sweden

\begin{abstract}
Serum concentrations of lipoprotein (a) [Lp (a)] were determined in two groups of elderly males suffering from prostatic carcinoma, who were randomized to treatment with estrogen ( $n$ $=15)$ or orchidectomy $(n=16)$. Estrogen was given as oral ethinylestradiol, $150 \mu \mathrm{g}$ daily, combined with intramuscular polyestradiol phosphate, $80 \mathrm{mg} / \mathrm{mo}$. The baseline levels were similar in both groups, but 6 mo after initiation of therapy, serum $L_{p}$ (a) levels were decreased $\sim 50 \%$ in the estrogentreated group $(P<0.001)$ in contrast to a $20 \%$ increase $(P$ $<0.01$ ) in the orchidectomized group. Concomitantly, LDL cholesterol decreased by $30 \%$ and HDL cholesterol increased by almost $60 \%$ in the estrogen-treated patients. There was no relationship between the change in LDL cholesterol and Lp (a) reduction. In conclusion, $L p$ (a) levels in males were found to drastically decrease upon estrogen treatment and to increase after orchidectomy, suggesting that sex hormones, and particularly estrogens, exert a regulatory role on the serum $\mathrm{Lp}$ (a) level in man. (J. Clin. Invest. 1992. 89:1166-1171.) Key words: Lp (a) lipoprotein • LDL receptors • estrogen • orchidectomy • coronary heart disease
\end{abstract}

\section{Introduction}

Lipoprotein (a) [Lp (a) $]^{1}$ is a complex between low density lipoprotein and apolipoprotein (a), the level of which is a strong independent risk factor for premature ischemic heart disease (1-12). Apo (a) is a glycoprotein which is linked to the structural protein of LDL, apo B-100, by a disulphide linkage, and which shows considerable size variation (from $\approx 300$ to $\approx 800$ $\mathrm{kD}$ ) among individuals owing to different numbers of cysteinerich sequences that are homologous to kringle 4 of plasminogen $(2,3,13-17)$. The size variation is inversely related to the serum concentration; thus, the lower molecular weight isoforms are present in higher concentrations (2, 3, 15-21).

The mechanisms for $\mathrm{Lp} \mathrm{(a)} \mathrm{synthesis} \mathrm{and} \mathrm{clearance} \mathrm{are}$ largely unknown, and no clear evidence of variation with age, sex, or diet has been described (1-3, 22-24). In familial hypercholesterolemia, the serum concentration of $\mathrm{Lp}$ (a) is fre-

Address correspondence to Dr. Bo Angelin, Department of Medicine, Huddinge University Hospital, S-141 86 Huddinge, Sweden.

Received for publication 13 September 1991 and in revised form 5 December 1991.

1. Abbreviations used in this paper: $\mathrm{FSH}$, follicle-stimulating hormone; GH, growth hormone; $\mathrm{Lp}(\mathrm{a})$, lipoprotein (a).

J. Clin. Invest.

(C) The American Society for Clinical Investigation, Inc. $0021-9738 / 92 / 04 / 1166 / 06 \$ 2.00$

Volume 89, April 1992, 1166-1171 quently increased $(12,25-27)$. The role of the LDL receptor in the clearance of $\mathrm{Lp}(\mathrm{a})$ is still debated, however. Thus, no reduction in Lp (a) levels has been observed during treatment with drugs known to stimulate the elimination of LDL from plasma via induction of LDL receptors, such as cholestyramine and cholesterol synthesis inhibitors $(12,28-30)$. On the other hand, overexpression of the human LDL receptor in transgenic mice clearly increases the plasma clearance of $L p(a)$ (31). The only hypolipidemic agent reported to lower $\mathrm{Lp}$ (a) levels is nicotinic acid (32), particularly when combined with neomycin (33). This has been taken as evidence for the concept that changes in $\mathrm{Lp}$ (a) synthesis rate may be more important than changes in clearance in the determination of serum Lp (a) levels $(1-3)$.

An interesting model for studying the regulation of serum Lp (a) levels in man emerges from our studies on lipoprotein metabolism in males treated with estrogen or orchidectomy due to prostatic carcinoma $(34,35)$. During estrogen treatment there is a profound stimulation of LDL clearance, accompanied by a distinctly increased production of LDL particles (35). Also, preliminary evidence for a reduced $\mathrm{Lp}$ (a) concentration during combined treatment with estrogen and progestagen has recently been presented (36). In the present study, we have therefore compared the effects of estrogen therapy and orchidectomy on serum $\operatorname{Lp}$ (a) concentrations, and found evidence for an important hormonal regulation of this lipoprotein fraction.

\section{Methods}

Subjects, experimental procedure. We studied 31 elderly males with recently diagnosed prostatic cancer suitable for hormonal treatment as judged by a senior urologist. Patients with a history or signs of previous thromboembolism, cerebrovascular lesion, myocardial infarction, severe angina pectoris, severe intermittent claudication, or congestive heart failure were excluded from the study. Altogether 23 of the patients have been included in our previous report on gallstone incidence (34).

After informed consent, the patients were randomly allocated either to orchidectomy $(n=16)$ or estrogen therapy $(n=15)$. Estrogen was given as polyestradiol phosphate, $160 \mathrm{mg}$ intramuscularly monthly for the first $3 \mathrm{mo}$, followed by $80 \mathrm{mg}$ intramuscularly monthly. In addition, the patients were given ethinyl estradiol, $1 \mathrm{mg}$ per os daily for the first $2 \mathrm{wk}$ and then $150 \mu \mathrm{g}$ daily. This dosage is the lowest one recommended in Sweden for the treatment of prostatic cancer. Serum samples were obtained in the morning between 8 and 9 a.m. after an overnight fast and stored at $-70^{\circ} \mathrm{C}$ until analyzed.

The ethical aspects of the study were approved by the ethical committee at Huddinge University Hospital, Sweden.

Materials. Acrylamide, ( $N, N^{\prime}$-methylene) bisacrylamide, and SDS were from Bio-Rad Laboratories (Richmond, CA). Monoclonal ${ }^{125} \mathrm{I}-$ antihuman $L p(a)$ antibodies were supplied as a kit (Pharmacia LKB, Uppsala, Sweden). Bovine serum albumin (fraction V) was purchased from Sigma Chemical Co. (St. Louis, MO). 
Serum hormone analysis. Serum concentrations of testosterone, follicle stimulating hormone (FSH), luteinizing hormone, and growth hormone $(\mathrm{GH})$ were determined by radioimmunoassay using kits from Diagnostic Products Corp., Los Angeles, CA; Farmos Diagnostica OY, Turku, Finland; and Pharmacia LKB, Uppsala, Sweden.

Serum lipoprotein and apolipoprotein analysis. Total serum cholesterol and triglyceride were determined with standard enzymatic techniques (Boehringer Mannheim GmbH, Mannheim, Germany). HDL cholesterol was determined after precipitation with heparin- $\mathrm{Mn}_{\mathbf{2}}$, and the concentration of LDL cholesterol was calculated according to the formula of Friedewald (37).

The serum concentration of $\mathrm{Lp}$ (a) was determined in duplicate with a two-site immunoradiometric assay (Pharmacia Diagnostics AB, Uppsala, Sweden). The method uses two monoclonal antibodies to different epitopes of human apo (a), one labeled with ${ }^{125} \mathrm{I}$ and one coupled to microsepharose. The detection limit of the assay was 12 $\mathrm{mg} /$ liter. The coefficient of variation was $3.8 \%$ at a standard concentration of $364 \mathrm{mg} /$ liter and $7.2 \%$ at a standard concentration of $137 \mathrm{mg} /$ liter. The Lp (a) serum standard was obtained from Immuno AG (Vienna, Austria; lot no. 2900-090).

SDS-polyacrylamide gel electrophoresis. Apo (a) isoform size was determined by SDS-PAGE of whole serum with subsequent Western blotting (38). Briefly, $20 \mu \mathrm{l}$ of serum was mixed with $200 \mu \mathrm{l}$ sample buffer ( $1 \%$ SDS, $20 \%$ glycerol, $0.1 \%$ bromophenol blue, $100 \mathrm{mM}$ Tris$\mathrm{HCl}, \mathrm{pH} 6.8$ ) and $8.8 \mu \mathrm{l} \beta$-mercaptoethanol and the solution was boiled for $10 \mathrm{~min}$. Aliquots were used for electrophoresis which was performed according to Laemmli (39) in a 3-8\% gradient gel using a vertical electrophoresis apparatus (Bio-Rad Laboratories). The electrophoresis was run for $4 \mathrm{~h}$ at $45 \mathrm{~mA}$. The transfer of proteins to nitrocellulose filters was performed overnight at $4^{\circ} \mathrm{C}$ according to Towbin et al. (40) at $300-500 \mathrm{~mA}$ in a cell blotting chamber (Bio-Rad Laboratories). Immunoblotting was performed using the ${ }^{125}$ I-labeled monoclonal anti-Lp (a) antibody described above. The filters were blocked by incubation for $1 \mathrm{~h}$ at room temperature with 5\% BSA, $0.01 \%$ antifoam $\mathrm{A}$, $0.2 \% \mathrm{NP} 40,80 \mathrm{mM} \mathrm{NaCl}, 2 \mathrm{mM} \mathrm{CaCl}, 50 \mathrm{mM}$ Tris-HCl, pH 8.0. Incubation then continued for $1 \mathrm{~h}$ in the same buffer at room temperature with added ${ }^{125} \mathrm{I}$-anti-Lp (a) antibody $\left(3-4 \times 10^{6} \mathrm{cpm} / 30 \mathrm{ml}\right)$. The filters were then washed in the incubation buffer, twice with and once without $0.5 \%$ BSA. Apparent molecular weight of apo B was estimated from the migration of human LDL standards.

Statistical analysis. Data are presented as means \pm SEM or, for Lp (a), as means (range). Student's $t$ test for paired and unpaired samples was used to compare baseline characteristics and changes after six months of therapy. Due to the skewed distribution of apo (a) levels, they were compared using Mann-Whitney's U test or Wilcoxon's signed rank test. The relative change in $\operatorname{Lp}(\mathrm{a})$ was found to be normally distributed. Consequently, regression was performed with the relative change in $\mathrm{Lp} \mathrm{(a)}$ as the dependent variable and the relative changes in the other lipids as tentative explanatory variables. Multiple stepwise regression was performed using a critical value of the $F$-distribution $(F$ value) of 4.0 to include and 3.996 to exclude independent variables.

\section{Results}

The two groups of male patients with prostatic cancer were well matched as regards baseline characteristics, including age (estrogen treatment, $68 \pm 1 \mathrm{yr}$; orchidectomy group $67 \pm 1 \mathrm{yr}$ ) and body weight (estrogen-treated group $68 \pm 3 \mathrm{~kg}$; orchidectomy $70 \pm 2 \mathrm{~kg}$ ). There was no significant change in weight after six months of therapy (estrogen-treated group, $69 \pm 2 \mathrm{~kg}$; orchidectomy group, $71 \pm 3 \mathrm{~kg}$ ). As expected, both groups displayed a drastic reduction of serum testosterone levels in response to therapy (Table I). The FSH and luteinizing hormone concentrations were distinctly increased in the orchidectomy group. In contrast, the serum GH levels were increased by estrogen therapy, and tended to be lower after orchidectomy (Table I).

As seen in Table II, the baseline lipoprotein values were similar in the two groups. The baseline $\mathrm{Lp} \mathrm{(a)} \mathrm{levels} \mathrm{in} \mathrm{both}$ groups were similar to the level in a corresponding normal population when assayed under identical conditions (mean level, $140 \mathrm{mg} /$ liter, $n=33$ ). In agreement with our previous results $(34,35)$, estrogen therapy resulted in a drastic lowering of LDL cholesterol and a marked increase in HDL cholesterol levels after six months of therapy, whereas no consistent changes in lipoprotein levels were observed after orchidectomy.

Distinct changes in $\mathrm{Lp}$ (a) levels were induced by both forms of treatment (Table II; Fig. 1). Thus, estrogen treatment markedly reduced serum $L p(a)$ levels, with a mean decrease of $51 \%(P<0.001)$. Of the 15 patients in the estrogen-treated group, a decrease in $\operatorname{Lp}$ (a) was found in 13, and in many cases the decrease was pronounced (Fig. 1). In contrast, Lp (a) levels were increased by a mean of $20 \%$ in the orchidectomized group $(P<0.01)$.

Since there is a wide variation in serum $\mathrm{Lp}$ (a) levels, and this variation to a major extent is determined by the specific apo (a) phenotype, it was of particular importance to study the individual response in subjects with varying apo (a) phenotypes. As exemplified in Fig. 2, the changes in Lp (a) concentrations could be demonstrated, regardless of protein size isoform. No relationship was observed between apo (a) phenotype and the magnitude of change in Lp (a) level in this limited series of patients. Furthermore, there were no identifiable differences in the clinical characteristics of the individuals who did not display the general pattern of response to treatment.

Additional support for the concept of opposite effects of estrogen treatment and orchidectomy on serum $\mathrm{Lp}$ (a) levels could be gained from the data obtained in three patients with

Table I. Effects on Serum Hormone Levels in Patients with Prostatic Cancer Treated with Estrogen or Orchidectomy

\begin{tabular}{|c|c|c|c|c|}
\hline & \multicolumn{2}{|c|}{ Estrogen } & \multicolumn{2}{|c|}{ Orchidectomy } \\
\hline & \multicolumn{2}{|c|}{$(n=15)$} & \multicolumn{2}{|c|}{$(n=16)$} \\
\hline & Baseline & $6 \mathrm{mo}$ & Baseline & $6 \mathrm{mo}$ \\
\hline Testosterone ( $\mathrm{nmol} /$ liter) & $17.8 \pm 1.9$ & $0.9 \pm 0.1^{*}$ & $22.7 \pm 2.0$ & $0.7 \pm 0.1^{*}$ \\
\hline Follicle-stimulating hormone (arbitrary U/liter) & $6.4 \pm 0.6$ & $6.5 \pm 2.6^{\ddagger}$ & $5.7 \pm 0.7$ & $24.6 \pm 2.8^{*}$ \\
\hline Luteinizing hormone (arbitrary U/liter) & $8.9 \pm 1.1$ & $5.7 \pm 1.9^{\ddagger}$ & $7.8 \pm 0.6$ & $25.4 \pm 3.6^{*}$ \\
\hline Growth hormone $(\mu g /$ liter $)$ & $1.6 \pm 0.5$ & $6.6 \pm 1.7^{\delta 1}$ & $2.1 \pm 0.8$ & $0.5 \pm 0.2$ \\
\hline
\end{tabular}

* Significantly different from baseline, $P<0.001 ;{ }^{\S} P<0.01$.

' Significantly different from orchidectomy, $P<0.01 ;{ }^{\ddagger} P<0.001$.

Means \pm SEM. 


\begin{tabular}{|c|c|c|c|c|}
\hline & \multicolumn{2}{|c|}{ Estrogen } & \multicolumn{2}{|c|}{ Orchidectomy } \\
\hline & \multicolumn{2}{|c|}{$(n=15)$} & \multicolumn{2}{|c|}{$(n=16)$} \\
\hline & Baseline & $6 \mathrm{mo}$ & Baseline & $6 \mathrm{mo}$ \\
\hline Cholesterol (mmol/liter) & $5.2 \pm 0.2$ & $5.0 \pm 0.2$ & $5.4 \pm 0.2$ & $5.4 \pm 0.3$ \\
\hline Triglycerides (mmol/liter) & $1.4 \pm 0.1$ & $1.7 \pm 0.2$ & $1.5 \pm 0.2$ & $1.6 \pm 0.2$ \\
\hline HDL cholesterol ( $\mathrm{mmol} /$ liter) & $1.2 \pm 0.1$ & $1.9 \pm 0.1^{\ddagger \S}$ & $1.3 \pm 0.1$ & $1.4 \pm 0.1$ \\
\hline LDL cholesterol ( $\mathrm{mmol} /$ liter) & $3.4 \pm 0.2$ & $2.3 \pm 0.2^{1 \|}$ & $3.3 \pm 0.2$ & $3.4 \pm 0.2$ \\
\hline Lipoprotein (a) $(m g / l i t e r)^{*}$ & $134(<12-434)$ & $66(<12-193)^{\ddagger}$ & $141(<12-577)$ & $168(<12-588)^{1}$ \\
\hline
\end{tabular}

* Mean (range).

' $P<0.01 ;{ }^{\ddagger} P<0.001$ compared to baseline.

${ }^{\S} P<0.01 ; " P<0.001$ compared to orchidectomy.

Means \pm SEM.

To convert mmol/liter to $\mathrm{mg} / \mathrm{dl}$, multiply cholesterol by 38.7 and triglycerides by 88.5 .

prostatic cancer who first received estrogen therapy for six months, and subsequently were switched to treatment with orchidectomy due to lack of clinical improvement. From analysis of these patients (Table III), it is very clear that the pronounced effect of estrogen was reversed in response to orchidectomy.

When the change in $\mathrm{Lp}(\mathrm{a})$ level in the 31 patients was analyzed in relation to the other lipoprotein changes, there was a significant relation to the relative change in HDL cholesterol

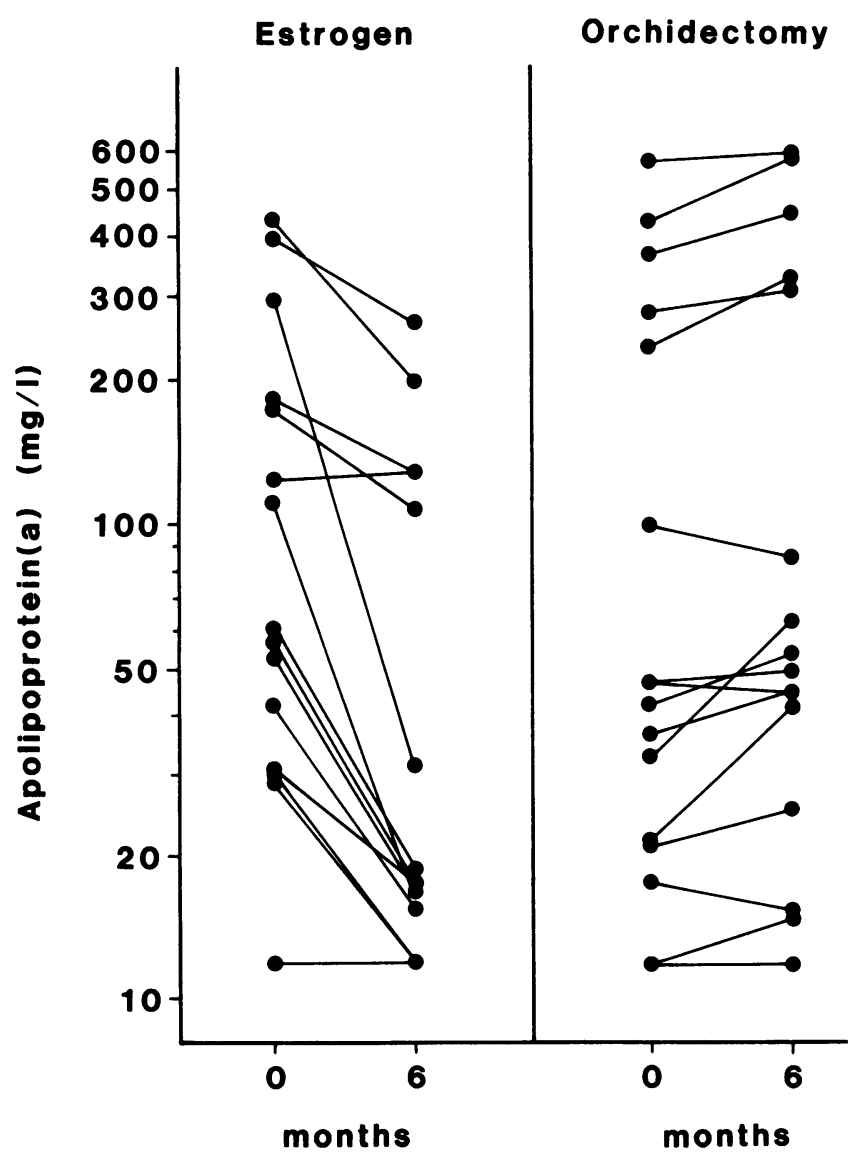

Figure 1. Individual serum $\mathrm{Lp}$ (a) levels at baseline and after six months treatment with estrogen or orchidectomy. Values below the detection limit of the assay (12 mg/liter) are displayed as $12 \mathrm{mg} /$ liter.
( $r=0.62, P=0.0004)$ but not to that in LDL cholesterol. Furthermore, no relations between the relative changes in $\mathrm{Lp}$ (a) and those in hormone levels were observed in the treated groups. When multiple regression analysis was performed the relative change in $\mathrm{Lp}$ (a) concentration could in part be explained by the relative changes in HDL cholesterol and triglyceride levels (relative change in $\operatorname{Lp}[\mathrm{a}]=[1.1-0.7 \times$ relative change in HDL cholesterol $-0.2 \times$ relative change in triglyceride]).

\section{Discussion}

The serum concentration of $\operatorname{Lp}(a)$ is under strict genetic control (1-3). However, in addition to variation of the number of kringle 4 repeats, the level of $\operatorname{Lp~(a)~is~clearly~influenced~by~}$ other factors, both genetic and nongenetic. The pronounced polymorphism of apo (a) in the population has considerably hampered studies of potentially important regulatory mechanisms, such as hormonal influences. It is of some interest that in one animal model, the European hedgehog, in which $\mathrm{Lp}$ (a) is the major apo B-containing lipoprotein (41), there is a profound seasonal variation of $\operatorname{Lp}(a)$ concentration which appears to be related to serum testosterone levels (42). In previous human studies, no significant differences between sexes in $\mathrm{Lp}$ (a) levels have been reported $(23,24)$. However, higher serum levels of $L p(a)$ have been reported in postmenopausal compared to premenopausal females (23). Except for two brief reports $(36,43)$, there is very little information on the effects of hormonal treatment on $\operatorname{Lp}(a)$ levels in man.

In the present study, we could clearly demonstrate significant and contrasting effects of two hormonal interventions in elderly males with prostatic cancer. In response to orchidectomy, resulting in lowered serum testosterone levels, there was a $20 \%$ mean increase in serum $\mathrm{Lp}$ (a) levels, regardless of apo (a) phenotype. In marked contrast, estrogen treatment resulted in drastic reductions in serum $\mathrm{Lp}$ (a) levels, again regardless of size isoform. Thus, it would seem that the presence of sex hormone suppresses $\mathrm{Lp}$ (a) levels, and the fact that both male and female hormones appear to have a lowering effect may be relevant for the lack of observed sex differences $(23,24)$. The estrogen doses used in the present study were, however, pharmacological, and the results may thus not be comparable to those 
A

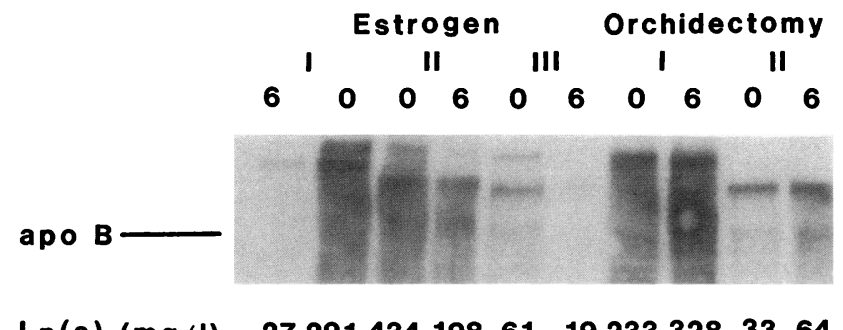

$L_{p}(a)(m g / I) \quad 2729143419861 \quad 192333283364$

obtained in response to the hormone levels observed under physiological conditions. In this context, it is nevertheless of interest to note that a lowering of $\mathrm{Lp}$ (a) levels has been observed during treatment with the anabolic steroid stanozolol in postmenopausal females (43).

Although the results of the present study were distinct, it is difficult to fully explain the mechanisms through which estrogen treatment or orchidectomy regulate $\mathrm{Lp}$ (a) levels. According to current view, the synthesis of $L p(a)$ is more important than its clearance in determining the final serum concentration (1-3). Thus, turnover studies have failed to explain the increased $L p$ (a) levels in familial hypercholesterolemia by a reduced fractional catabolic rate $(44,45)$ and pharmacological treatment aimed at reducing lipoprotein synthesis, such as nicotinic acid therapy, appears to be more efficient in reducing $\mathrm{Lp}$ (a) levels $(32,33)$. In males treated with estrogen, the formation of LDL is increased by almost $30 \%$, however (35), which clearly contrasts against the $50 \%$ reduction in $\mathrm{Lp}$ (a) levels observed in the present study during an identical regime. It is of course possible that sex hormones, and particularly estrogen, influence the assembly of apo (a) to apo B which is believed to occur through a disulphide linkage in the hepatocyte $(2,3)$. Indirect evidence that such a mechanism may be of importance emerges from the recent finding of a reduced $\mathrm{Lp}$ (a) concentration in individuals with high Lp (a) levels during treatment with the reducing agent acetylcysteine (46).

Table III. Effects on Serum Cholesterol and Lp (a) Levels in Three Patients with Prostatic Carcinoma before and after Treatment with Estrogen for Six Months, and Six Months after Subsequent Orchidectomy and Cessation of Estrogen Therapy

\begin{tabular}{|c|c|c|c|}
\hline & Basal & $\begin{array}{l}\text { Estrogen } \\
\text { treatment }\end{array}$ & Orchidectomy \\
\hline \multicolumn{4}{|l|}{ Patient 1 ( $70 \mathrm{yr} ; 72 \mathrm{~kg})$} \\
\hline Total cholesterol ( $\mathrm{mmol} / \mathrm{liter})$ & 8.1 & 5.7 & 8.9 \\
\hline HDL cholesterol $(\mathrm{mmol} / \mathrm{liter})$ & 0.9 & 1.6 & 1.2 \\
\hline $\operatorname{Lp}(\mathrm{a})(m g / l i t e r)$ & 423 & 219 & 473 \\
\hline \multicolumn{4}{|l|}{ Patient 2 (69 yr; $85 \mathrm{~kg})$} \\
\hline Total cholesterol (mmol/liter) & 6.3 & 5.1 & 7.6 \\
\hline HDL cholesterol ( $\mathrm{mmol} / \mathrm{liter})$ & 1.1 & 2.2 & 1.3 \\
\hline Lp (a) (mg/liter) & 112 & $<12$ & 165 \\
\hline \multicolumn{4}{|l|}{ Patient 3 (71 yr; $63 \mathrm{~kg})$} \\
\hline Total cholesterol ( $\mathrm{mmol} /$ liter) & 5.6 & 4.5 & 6.4 \\
\hline HDL cholesterol ( $\mathrm{mmol} / \mathrm{liter})$ & 1.2 & 2.0 & 1.0 \\
\hline $\operatorname{Lp}(\mathrm{a})(\mathrm{mg} /$ liter $)$ & 18 & $<12$ & 25 \\
\hline
\end{tabular}

To convert $\mathrm{mmol} /$ liter to $\mathrm{mg} / \mathrm{dl}$, multiply cholesterol by 38.7 .
B

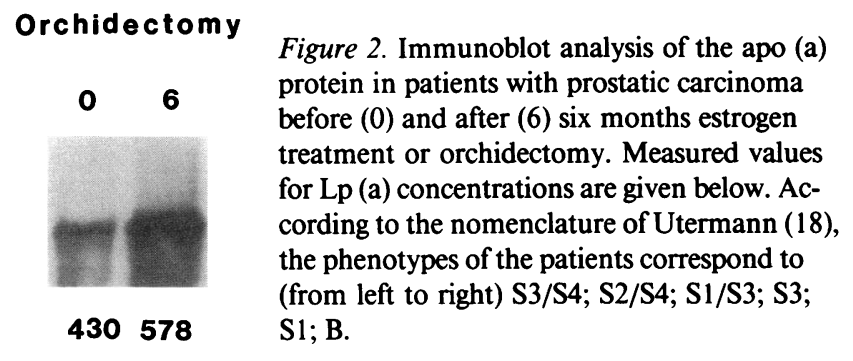

During estrogen treatment in males, the fractional catabolic rate of LDL apo B is increased by $\sim 80 \%$ (35) due to a threefold induction of hepatic LDL receptors (Angelin, B., H. Olivecrona, M. Rudling, E. Reihnér, S. Ewerth, P. Henriksson, and K. Einarsson, submitted for publication). This results in clear reductions of LDL cholesterol levels, as also observed in the present study. It is now evident that $\mathrm{Lp}$ (a) can be cleared through LDL receptor-mediated mechanisms, although the catabolism may be somewhat reduced compared to that of LDL $(31,44,47-49)$. In fact, treatment with drugs such as cholestyramine and cholesterol synthesis inhibitors, which are known to induce hepatic LDL receptor expression in man $(50,51)$, do not reduce, and sometimes may even increase, $L p(a)$ levels $(12,28-30)$. However, recent studies using a drastic induction of human LDL receptors in transgenic mice have demonstrated the possibility for an enhanced clearance of $L p(a)$ particles during stimulation of the LDL receptor pathway (31). Thus, it is still possible that at least part of the estrogen-mediated effect on Lp (a) serum concentration observed in our study is mediated through an increased clearance. However, no correlation between the change in $\operatorname{Lp}$ (a) concentration and the change in LDL cholesterol level was observed in the estrogentreated group. Thus, studies using kinetic analysis of $\mathrm{Lp}$ (a) turnover are needed to establish the relative importance of $L p$ (a) clearance and synthesis for the effects of estrogen. The importance of testosterone, and "normal" levels of estrogen, may well be exerted through effects on Lp (a) synthesis, although this cannot be decided presently. Finally, although we could not find any statistical correlation to the changes in the concentrations of other hormones induced by estrogen treatment or orchidectomy, further studies are needed to ascertain whether or not some treatment effects may be mediated by secondary hormonal changes.

The distinct effects of sex hormones, and particularly exogenous estrogen, on serum $\mathrm{Lp}$ (a) levels may have some clinical relevance. Thus, in addition to the effects on LDL and HDL cholesterol levels, a reduced level of $L p$ (a) may have an important role in explaining the apparently reduced risk for ischemic heart disease and stroke in estrogen-treated postmenopausal females (52-54). Preliminary evidence for a reduced $\mathrm{Lp} \mathrm{(a)}$ concentration during combined treatment with estrogen and progestagen has recently been presented (36). However, the complexity of the metabolic response to estrogen should be evident from the fact that estrogen-treated males with prostatic cancer actually have a higher risk for subsequent cardiovascular events when compared to those treated by orchidectomy $(55,56)$.

In conclusion, $\operatorname{Lp}(\mathrm{a})$ levels in males were found to decrease drastically upon estrogen treatment and to increase after orchi- 
dectomy, suggesting that sex hormones, particularly estrogen, exert a regulatory role of the serum $\mathrm{Lp}$ (a) level in man.

\section{Acknowledgments}

The skillful technical assistance of Ms. Tatiana Egereva and Ms. Lilian Larsson, and the manuscript preparation by Ms. Lena Ericsson, are gratefully acknowledged.

This study was supported by grants from the Swedish Medical Research Council (03X-7137 and 03K-8722), the Swedish Heart-Lung Foundation, and the King Gustaf V and Queen Victoria Foundation.

\section{References}

1. Morrisett, J. D., J. R. Guyton, J. W. Gaubatz, and A. M. Gotto, Jr. 1987. Lipoprotein (a): structure, metabolism and epidemiology. In Plasma Lipoproteins. A. M. Gotto, Jr., editor. Elsevier Science Publishers B.V., Amsterdam. 129-152.

2. Utermann, G. 1989. The mysteries of lipoprotein (a). Science (Wash. DC). 246:904-910.

3. Scanu, A. M., and G. M. Fless. 1990. Lipoprotein (a). Heterogeneity and biological relevance. J. Clin. Invest. 85:1709-1715.

4. Berg, K., G. Dahlén, and M. H. Frick. 1974. Lp (a) lipoprotein and prebeta-1-lipoprotein in patients with coronary heart disease. Clin. Genet. 6:230235.

5. Kostner, G. M., P. Avogaro, G. Cazzolato, E. Marth, G. Bittolo-Bon, and G. B. Qunici. 1981. Lipoprotein Lp (a) and the risk for myocardial infarction. Atherosclerosis. 38:51-61.

6. Armstrong, V. W., P. Cremer, E. Eberle, A. Manke, F. Schulze, H. Wieland, H. Kreuzer, and D. Seidel. 1986. The association between serum Lp (a) concentrations and angiographically assessed coronary atherosclerosis. Dependence on serum LDL levels. Atherosclerosis. 62:249-257.

7. Dahlén, G. H., J. R. Guyton, M. Attar, J. A. Farmer, J. A. Kautz, and A. M. Gotto. 1986. Association of levels of lipoprotein Lp (a), plasma lipids, and other lipoproteins with coronary artery disease documented by angiography. Circulation. 74:758-765.

8. Rhoads, G. G., G. Dahlén, K. Berg, N. E. Morton, and A. L. Dannenberg. 1986. Lp (a) lipoprotein as risk factor for myocardial infarction. JAMA (J. Am. Med. Assoc.). 256:2540-2544.

9. Durrington, P. N., M. Ishola, L. Hunt, S. Arrol, and D. Bhatnagar. 1988. Apolipoproteins (a), AI, and B and parental history in men with early onset ischaemic heart disease. Lancet. i:1070-1073.

10. Sandkamp, M., H. Funke, H. Schulte, E. Köhler, and G. Assman. 1990. Lipoprotein (a) is an independent risk factor for myocardial infarction at a young age. Clin. Chem. 36:20-23.

11. Seed, M., F. Hoppichler, D. Reaveley, S. McCarthy, G. Thompson, E Boerwinkle, and G. Utermann. 1990. Relation of serum lipoprotein (a) concentration and apolipoprotein (a) phenotype to coronary heart disease in patients with familial hypercholesterolemia. $N$. Engl. J. Med. 322:1494-1499.

12. Wiklund, O., B. Angelin, S.-O. Olofsson, M. Eriksson, G. Fager, L. Berglund, and G. Bondjers. 1990. Apolipoprotein (a) and ischaemic heart disease in familial hypercholesterolaemia. Lancet. 335:1360-1363.

13. Eaton, D. L., G. M. Fless, W. J. Kohr, J. W. McLean, Q. T. Xu, C. G. Miller, R. M. Lawn, and A. M. Scanu. 1987. Partial amino acid sequence of apolipoprotein (a) shows that it is homologous to plasminogen. Proc. Natl. Acad. Sci. USA. 84:3224-3228.

14. McLean, J. W., J. E. Tomlinson, W.-J. Kuang, D. L. Eaton, E. Y. Chen, G. M. Fless, A. M. Scanu, and R. M. Lawn. 1987. cDNA sequence of human apolipoprotein (a) is homologous to plasminogen. Nature (Lond.). 300:132-137.

15. Gavish, D., N. Azrolan, and J. L. Breslow. 1989. Plasma Lp(a) concentration is inversely correlated with the ratio of kringle IV/kringle V encoding domains in the apo (a) gene. J. Clin. Invest. 84:2021-2027.

16. Koschinsky, M. L., U. Beisiegel, D. Henne-Bruns, D. L. Eaton, and R. M Lawn. 1990. Apolipoprotein (a) size heterogeneity is related to variable number of repeat sequences in its mRNA. Biochemistry. 29:640-644.

17. Lackner, C., E. Boerwinkle, C. C. Leffert, T. Rahmig, and H. Hobbs. 1991. Molecular basis of apolipoprotein (a) isoform size heterogeneity as revealed by pulsed-field gel electrophoresis. $J$. Clin. Invest. 87:2153-2161.

18. Utermann, G., H. J. Menzel, H. G. Kraft, H. C. Duba, H. G. Kemmler, and C. Seitz. 1987. Lp (a) glycoprotein phenotypes. Inheritance and relation to Lp (a)-lipoprotein concentrations in plasma. J. Clin. Invest. 80:458-465.

19. Utermann, G., H. G. Kraft, H. J. Menzel, T. Hopferwieser, and C. Seitz. 1988. Genetics of the quantitative $\mathrm{Lp}$ (a) lipoprotein trait. I. Relation of $\mathrm{Lp}$ (a) glycoprotein phenotypes to Lp (a) lipoprotein concentrations in plasma. Hum. Genet. 78:41-46.

20. Utermann, G., C. Duba, and H. J. Menzel. 1988. Genetics of the quantita- tive $\mathrm{Lp}$ (a) lipoprotein trait. II. Inheritance of $\mathrm{Lp}$ (a) glycoprotein phenotypes. Hum. Genet. 78:47-50.

21. Gaubatz, J. W., K. I. Ghanem, J. Guevara, Jr., M. L. Nava, W. Patsch, and J. D. Morrisett. 1990. Polymorphic forms of human apolipoprotein [a]: inheritance and relationship of their molecular weights to plasma levels of lipoprotein [a]. J. Lipid Res. 31:603-613.

22. Boerwinkle, E., H. J. Menzel, H. G. Kraft, and G. Utermann. 1989. Genetics of the quantitative $\mathrm{Lp}$ (a) lipoprotein trait. III. Contribution of $\mathrm{Lp}$ (a) glycoprotein phenotypes to normal lipid variation. Hum. Genet. 82:73-78.

23. Guyton, J. R., G. H. Dahlén, W. Patsch, J. A. Kautz, and A. M. Gotto, Jr. 1985. Relationship of plasma lipoprotein Lp (a) levels to race and to apolipoprotein B. Arteriosclerosis. 5:265-272.

24. Schriewer, H., G. Assman, M. Sandkamp, and H. Schulte. 1984. The relationship of lipoprotein (a) $[\mathrm{Lp}(\mathrm{a})]$ to risk factors for coronary heart disease. $J$. Clin. Chem. Clin. Biochem. 22:591-596.

25. Utermann, G., F. Hoppichler, H. Dieplinger, M. Seed, G. Thompson, and E. Boerwinkle. 1989. Defects in the low density lipoprotein receptor gene affect lipoprotein (a) levels: multiplicative interaction of two gene loci associated with premature atherosclerosis. Proc. Natl. Acad. Sci. USA. 86:4171-4174.

26. Mbewu, A. D., D. Bhatnagar, P. N. Durrington, L. Hunt, M. Ishola, S. Arrol, M. Mackness, P. Lockley, and J. P. Miller. 1991. Serum lipoprotein (a) in patients heterozygous for familial hypercholesterolemia, their relatives, and unrelated control populations. Arteriosclerosis Thromb. 11:940-946.

27. Guo, H.-C., M. J. Chapman, E. Bruckert, J.-P. Farriaux, and J.-L. de Gennes. 1991. Lipoprotein Lp (a) in homozygous familial hypercholesterolemia: density profile, particle heterogeneity and apolipoprotein (a) phenotype. Atherosclerosis. 31:69-83.

28. Vessby, B., G. Kostner, H. Lithell, and J. Thomis. 1982. Diverging effects of cholestyramine on apolipoprotein B and lipoprotein (a). Atherosclerosis. 44:61-71.

29. Thiery, J., V. W. Armstrong, J. Schleef, C. Creutzfeldt, W. Creutzfeldt, and D. Seidel. 1988. Serum lipoprotein (a) concentrations are not influenced by an HMG CoA reductase inhibitor. Klin. Wochenschr. 66:462-463.

30. Kostner, G. M., D. Gavish, B. Leopold, K. Bolzano, M. S. Weintraub, and J. L. Breslow. 1989. HMG CoA reductase inhibitors lower LDL cholesterol without reducing Lp (a) levels. Circulation. 80:1313-1319.

31. Hofmann, S. L., D. L. Eaton, M. S. Brown, W. J. McConathy, J. L. Goldstein, and R. E. Hammer. 1990. Overexpression of human low density lipoprotein receptors leads to accelerated catabolism of $\mathrm{Lp}$ (a) lipoprotein in transgenic mice. J. Clin. Invest. 85:1542-1547.

32. Carlson, L. A., A. Hamsten, and A. Asplund. 1989. Pronounced lowering of serum levels of lipoprotein Lp (a) in hyperlipidaemic subjects treated with nicotinic acid. J. Intern. Med. 226:271-276.

33. Guraker, A., J. M. Hoeg, G. Kostner, N. M. Papadopoulos, and H. B. Brewer, Jr. 1985. Levels of lipoprotein (a) decline with neomycin and niacin treatment. Atherosclerosis. 57:293-301.

34. Henriksson, P., K. Einarsson, A. Eriksson, U. Kelter, and B. Angelin. 1989. Estrogen-induced gallstone disease in males. Studies on biliary lipid composition and gallstone formation during treatment of prostatic carcinoma. $J$. Clin. Invest. 84:811-816.

35. Eriksson, M., L. Berglund, M. Rudling, P. Henriksson, and B. Angelin. 1989. Effects of estrogen on low density lipoprotein metabolism in males. Shortterm and long-term studies during hormonal treatment of prostatic carcinoma. $J$. Clin. Invest. 84:802-810.

36. Soma, M., R. Fumagalli, R. Paoletti, M. Meschia, M. C. Maini, P. Crosignani, K. Ghanem, J. Gaubatz, and J. D. Morrisett. 1991. Plasma Lp(a) concentration after oestrogen and progestagen in postmenopausal women. (Letter.) Lancet. 337:612.

37. Friedewald, W. T., R. I. Levy, and D. S. Fredrickson. 1972. Estimation of the concentration of low-density lipoprotein cholesterol in plasma, without use of the preparative ultracentrifuge. Clin. Chem. 18:499-502

38. Kraft, H.-G., H. Dieplinger, E. Hoye, and G. Utermann. 1988. Lp (a) phenotyping by immunoblotting with polyclonal and monoclonal antibodies. Arteriosclerosis. 8:212-216.

39. Laemmli, U. K. 1970. Cleavage of structural proteins during the assembly of the head of bacteriophage T4. Nature (Lond.). 227:680-685.

40. Towbin, H., T. Staehelin, and J. Gordon. 1979. Electrophoretic transfer of proteins from polyacrylamide gels to nitrocellulose sheets: procedure and some applications. Proc. Natl. Acad. Sci. USA. 76:4350-4354.

41. Laplaud, P., L. Beaubatie, S. C. Rall, Jr., G. Luc, and M. Saboureau. 1988. Lipoprotein [a] is the major apoB-containing lipoprotein in the plasma of a hibernator, the hedgehog (Erinaceus europaeus). J. Lipid Res. 29:1157-1170.

42. Laplaud, P. M., M. Saboureau, L. Beaubatie, and B. El-Omari. 1989. Seasonal variations of plasma lipids and lipoproteins in the hedgehog, an animal model for lipoprotein (a) metabolism: relation to plasma thyroxine and testosterone levels. Biochim. Biophys. Acta. 1005:143-156.

43. Albers, J. J., H. M. Taggart, D. Applebaum-Bowden, S. Haffner, C. H. Chesnut III, and W. R. Hazzard. 1984. Reduction of lecithin-cholesterol acyltransferase, apolipoprotein $\mathrm{D}$ and the $\mathrm{Lp}$ (a) lipoprotein with the anabolic steroid stanozolol. Biochim. Biophys. Acta. 795:293-296. 
44. Krempler, F., G. M. Kostner, A. Roscher, F. Haslauer, K. Bolzano, and F. S. Sandhofer. 1983. Studies on the role of specific cell surface receptors in the removal of lipoprotein (a) in man. J. Clin. Invest. 71:1431-1441.

45. Knight, B. L., Y. F. N. Perombelon, A. K. Soutar, D. P. Wade, and M. Seed. 1991. Catabolism of lipoprotein (a) in familial hypercholesterolaemic subjects. Atherosclerosis. 87:227-237.

46. Gavish, D., and J. L. Breslow. 1991. Lipoprotein (a) reduction by N-acetylcysteine. Lancet. 337:203-204.

47. Florén, C.-H., J. J. Albers, and E. L. Bierman. 1981. Uptake of Lp(a) lipoprotein by cultured fibroblasts. Biochem. Biophys. Res. Commun. 102:636639.

48. Havekes, L., B. J. Vermeer, T. Brugman, and J. Emeis. 1981. Binding of $\mathrm{Lp}(\mathrm{a})$ to the low density lipoprotein receptor of human fibroblasts. FEBS (Fed. Eur. Biochem. Soc.) Lett. 132:169-173.

49. Armstrong, V. W., A. K. Walli, and D. Seidel. 1985. Isolation, characterization, and uptake in human fibroblasts of an apo(a)-free lipoprotein obtained on reduction of lipoprotein (a). J. Lipid Res. 26:1314-1324.

50. Rudling, M., E. Reihnér, K. Einarsson, S. Ewerth, and B. Angelin. 1990. Low density lipoprotein receptor binding activity in human tissues: quantitative importance of hepatic receptors and evidence for regulation of their expression in vivo. Proc. Natl. Acad. Sci. USA. 87:3469-3473.

51. Reihnér, E., M. Rudling, D. Ståhlberg, L. Berglund, S. Ewerth, I. Björkhem, K. Einarsson, and B. Angelin. 1990. Influence of pravastatin, a specific inhibitor of HMG-CoA reductase, on hepatic metabolism of cholesterol. $N$. Engl. J. Med. 323:224-228.

52. Colditz, J. A., W. C. Willett, M. J. Stampfer, B. Rosner, F. E. Speitzer, and C. H. Hennekens. 1987. Menopause and the risk of coronary heart disease in women. N. Engl. J. Med. 316:1105-1110.

53. Paganini-Hill, A., R. K. Ross, and B. E. Henderson. 1988. Postmenopausal oestrogen treatment and stroke: a prospective study. Br. Med. J. 297:519522.

54. Barrett-Connor, E., and T. L. Bush. 1991. Estrogen and coronary heart disease in women. JAMA (J. Am. Med. Assoc.). 265:1861-1867.

55. Veterans Administration Cooperative Urological Research Group. 1967. Carcinoma of the prostate: treatment comparison. J. Urol. 98:516-522.

56. Henriksson, P., and O. Edhag. 1986. Orchidectomy versus oestrogen for prostatic cancer: cardiovascular effect. Br. Med. J. 293:413-415. 